\title{
The higher area-based photosynthesis in Gossypium hirsutum L. is mostly attributed to higher leaf thickness
}

\author{
J.M. HAN, Y.J. ZHANG, Z.Y. LEI, W.F. ZHANG, and Y.L. ZHANG ${ }^{+}$ \\ The Key Laboratory of Oasis Eco-agriculture, Xinjiang Production and Construction Group, Shihezi University, \\ 832003 Shihezi, China
}

\begin{abstract}
There is a trade-off between leaf structures and photosynthesis physiology. While numerous reports have shown a difference in photosynthesis between Gossypium hirsutum L. (upland cotton) and G. barbadense L. (pima cotton), the potential contribution of leaf structures on this difference was not fully clarified. Here, we investigated the differences in area- and mass-based photosynthetic traits and leaf structures between upland and pima cottons. Our results showed that upland cotton had higher area-based net photosynthetic rate $\left(P_{\text {area }}\right)$ than that of pima cotton, which was attributed to the coordination of stomatal conductance $\left(g_{\mathrm{s}}\right)$, area-based mesophyll conductance $\left(g_{\mathrm{m} \text {-area }}\right)$, and maximum carboxylation rate $\left(V_{\text {cmax-area }}\right) . P_{\text {area }}, g_{\mathrm{m} \text {-area }}$, and $V_{\text {cmax-area }}$ correlated positively with leaf mass per area. But upland and pima cotton had similar mass-based $P_{\mathrm{N}}\left(P_{\text {mass }}\right), g_{\mathrm{m}}\left(g_{\mathrm{m}-\text { mass }}\right), V_{\text {cmax }}\left(V_{\text {cmax-mass }}\right)$, suggesting that they have a similar photosynthetic capacity of single cells. Consequently, the higher area-based values in upland cotton were only due to a higher leaf thickness $\left(\mathrm{T}_{\text {leaf }}\right)$.
\end{abstract}

Additional key words: chlorophyll fluorescence; gas exchange; leaf density; leaf mass per area; nitrogen content.

\section{Introduction}

Leaf photosynthesis is determined by biochemical capacity (i.e., the maximum carboxylation rate, $V_{\mathrm{cmax}}$, and the maximum electron transport rate, $J_{\max }$ ) and $\mathrm{CO}_{2}$ diffusion conductance from the atmosphere to chloroplasts, including stomatal conductance $\left(g_{\mathrm{s}}\right)$ and mesophyll conductance $\left(g_{\mathrm{m}}\right)$ (Flexas et al. 2007, 2008, 2012, 2016; Evans et al. 2009, Terashima et al. 2011). These traits should be tightly coordinated, thus maximizing photosynthetic efficiency (Wright et al. 2004a). The $g_{\mathrm{s}}$ can be calculated relatively easily according to the concentration difference of water in and out of the stomata. But in vivo measurements of $g_{\mathrm{m}}$ are not as straightforward as those of net photosynthetic rate $\left(P_{\mathrm{N}}\right)$ and $g_{\mathrm{s}}$ (Gago et al. 2016). Therefore, in the last decades, $g_{\mathrm{m}}$ had been considered to be constant and infinite. Indeed, $g_{\mathrm{m}}$ is variable and sufficiently small as to significantly limit photosynthesis to an extent similar to that known for $g_{\text {s }}$ (Flexas et al. 2006, 2008). Furthermore, it has been shown that stomatal, mesophyll conductance, and biochemical limitations to photosynthesis are of similar magnitude in leaves of angiosperm species (Flexas 2016), but especially in crops (Nadal and Flexas 2018). Currently, there are three common $g_{\mathrm{m}}$ estimation methods including the variable $J$ method (Harley et al. 1992), the carbon isotope discrimination method (Evans et al. 1986), and the curvefitting method (Ethier and Livingston 2004, Sharkey et al. 2007, Sharkey 2016, Gu and Sun 2014), but they employ different assumptions and have their own shortcomings because of the very complex mesophyll diffusion process affected by many structural diffusion paths (e.g., leaf thickness, cell wall thickness, and chloroplast traits). Although a structures-based quantitative one-dimensional gas diffusion model of Niinemets and Reichstein (2003) as modified by Tosens et al. (2016) was also used to estimate $g_{\mathrm{m}}$, Parkhurst (1994) has indicated intercellular diffusion as fundamentally a three-dimensional process. Generally, the area-based photosynthetic parameters were often used to analyze the effects of leaf structures on photosyn-thetic traits, but some studies have shown that mass-based photosynthetic parameters can better reflect the photosynthetic capacity of single cells (Westoby et al. 2013, Niinemets et al. 2015). Photosynthesis depends largely on $\mathrm{CO}_{2}$ concentration at the sites of carboxylation within chloroplasts $\left(C_{\mathrm{c}}\right) ; \mathrm{CO}_{2}$ drawdown from the internal airspace to chloroplasts is a mesophyll-volume weighted average

\footnotetext{
$\overline{\text { Received }} 27$ August 2018, accepted 21 November 2018.

+Corresponding author; e-mail: zhangyali_cn@foxmail.com, zhangyali_shzu@163.com

Abbreviations: $C_{\mathrm{c}}-\mathrm{CO}_{2}$ concentration at the sites of carboxylation within chloroplasts; $C_{\mathrm{i}}-$ intercellular $\mathrm{CO}_{2}$ concentration; $\mathrm{D}_{\text {leaf }}-$ leaf density; $g_{\mathrm{m}}-$ mesophyll conductance; $g_{\mathrm{s}}-$ stomatal conductance; $J_{f u}-$ electron transport rate; $J_{\max }-$ the maximum electron transport rate; LMA - leaf mass per area; $l_{\mathrm{b}}$ - biochemical limitation; $l_{\mathrm{m}}$ - mesophyll limitation; $l_{\mathrm{s}}$ - relative stomatal limitation; $P_{\mathrm{N}}-$ net photosynthetic rate; $R_{\mathrm{D}}$ - dark respiration; $R_{\mathrm{d}}$ - day respiration; $\mathrm{T}_{\text {leaf }}-$ leaf thickness; $V_{\mathrm{cmax}}$ - the maximum carboxylation rate; $\alpha$ - leaf absorptance; $\beta$ - the partitioning of absorbed quanta between PSI and PSII.

Acknowledgements: This work was supported by the Program for The Excellent Youth Scholar of Higher Education of XPCC (CZ027201), Plan for Training Youth Innovative Talent in Shihezi University (CXRC201701), and National Natural Science Foundation of China (Grant No. U1303183). The authors also thank the China Scholarship Council (CSC) for the funding of joint training PhD.
} 
(Niinemets et al. 2005, Niinemets and Sack 2006). Therefore, Niinemets and Sack (2006) indicated that the massbased $g_{\mathrm{m}}\left(g_{\mathrm{m}-\mathrm{mass}}\right)$ is the true determinant of the volumeweighted average chloroplastic $\mathrm{CO}_{2}$ concentration. Ellsworth et al. (2018) also proposed that modeled $V_{\text {cmax }}$ and $J_{\max }$ normalized on a per-gram basis were effective in separating biochemical from anatomical effects on $P_{\mathrm{N}}$. Furthermore, the mass-based maximum $P_{\mathrm{N}}$ was more variable than the area-based maximum $P_{\mathrm{N}}$ in the global databases (Niinemets 1999, Wright et al. 2004b, Kattge et al. 2011), suggesting that the mass basis provides a more effective estimate of photosynthetic capacity for datasets with higher species coverage. An easily measurable leaf integrative structure trait, leaf mass per area (LMA), can be used to convert area-based photosynthetic parameters to mass-based ones. The relationships between area-based $P_{\mathrm{N}}$ $\left(P_{\text {area }}\right)$ and LMA are often variable. This is partly because leaf thickness $\left(\mathrm{T}_{\text {leaf }}\right)$ and leaf density $\left(\mathrm{D}_{\text {leaf }}\right)$, which are the most important intrinsic drivers of LMA (Niinemets 2015), may influence leaf photosynthetic capacity in different ways (Niinemets 1999). But the relationship between mass-based $P_{\mathrm{N}}\left(P_{\text {mass }}\right)$ and LMA was found to be stronger than that between the $P_{\text {area }}$ and LMA (Tosens et al. 2016). Numerous studies have indicated that low $P_{\text {mass }}$ is associated with thick robust leaves and thus high LMA (Reich et al. 1997, Niinemets 2001, Wright et al. 2004b). Moreover, $P_{\text {mass }}$ correlates positively with massbased nitrogen content $\left(\mathrm{N}_{\text {mass }}\right)$, thus the leaves with high $P_{\text {mass }}$ should have high nitrogen-use efficiency (Niinemets 2001, Wright et al. 2004a). The photosynthetic capacity per unit of nitrogen can be used to analyze the nitrogen investment proportion between anatomical structures and photosynthetic proteins. Consequently, the photosynthetic traits on the basis of mass should better reflect the trade-off between the physiological and structural characteristics of leaves (Westoby et al. 2013, Niinemets et al. 2015).

Gossypium hirsutum L. (upland) and G. barbadense L. (pima) are the most important fiber crops grown worldwide in more than 50 countries and play an important role in the global economy. They have obvious yield difference, fiber quality difference, and plant morphological difference. In previous works, it has been shown that upland cotton has higher photosynthesis than that of pima cotton due to larger $g_{s}$ and much more photosynthetic tissues reflected by higher palisade thickness (Zhang et al. 2011). But these data are from area-based photosynthetic physiological analysis. At present, no studies analyzed the photosynthetic physiological and structural trading between these two species. The aims of the study were (1) to determine if $g_{\mathrm{m}}$ also plays an important role in the difference of photosynthesis between upland and pima cotton; (2) to reveal if there is trade-off between mass-based photosynthetic traits and leaf structures in upland and pima cotton.

\section{Materials and methods}

Plant materials: Four representative cotton cultivars (upland cotton - Gossypium hirsutum L. cv. Xinluzao 45 and Xinluzao 33 and pima cotton - Gossypium barbadense L. cv. Xinhai 28 and Xinhai 25) were used in this study. The experiment was conducted in an experimental field (a clay loam) of Shihezi Agricultural College, Shihezi University, Xinjiang, China $\left(45^{\circ} 19^{\prime} \mathrm{N}, 8^{\circ} 03^{\prime} \mathrm{E}\right)$ in 2015. Seeds were sown on 21 April, 2015, in rows $12 \mathrm{~cm}$ apart at a plant density of $1.8 \times 10^{5} \mathrm{ha}^{-1}$. Cottons were drip irrigated according to local field irrigation level $(495 \mathrm{~mm})$. The plots were fertilized before sowing with $240 \mathrm{~kg}(\mathrm{~N}) \mathrm{ha}^{-1}$ (urea), $170 \mathrm{~kg}\left(\mathrm{P}_{2} \mathrm{O}_{5}\right) \mathrm{ha}^{-1}\left[\left(\mathrm{NH}_{4}\right)_{3} \mathrm{PO}_{4}\right]$, and 1,500 $\mathrm{kg} \mathrm{ha}^{-1}$ of organic fertilizer [235 $\mathrm{g}$ (organic matter) $\mathrm{kg}^{-1}$, $18 \mathrm{~g}($ total $\mathrm{N}) \mathrm{kg}^{-1}, 14 \mathrm{~g}($ total $\mathrm{P}) \mathrm{kg}^{-1}$, and $22 \mathrm{~g}$ (total $\left.\mathrm{K}\right) \mathrm{kg}^{-1}$ ]. An additional $120 \mathrm{~kg}(\mathrm{~N}) \mathrm{ha}^{-1}$ (urea) was applied by drip irrigation during the growing season. Weeds and pests were controlled in the field using standard management practices. Measurements were conducted on the topmost fully expanded leaf on the main stem of the cotton selected at random at the boll formation stage (about $80 \mathrm{~d}$ after sowing). Meteorological data during the growing season are shown in Fig. 1.

Leaf gas exchange and $\mathrm{Chl}$ fluorescence parameters were measured simultaneously using an open gas-exchange system ( $L i-6400, \mathrm{Li}$-Cor, Inc., Lincoln, NE, USA) connected to leaf fluorometer chamber $\left(2 \mathrm{~cm}^{2}, L i-6400-40\right.$, Li-Cor, Inc., Lincoln, NE, USA). At least three $\mathrm{CO}_{2}$ response curves were measured per cultivars using lightadapted mature leaves. Leaf temperature was set to $30^{\circ} \mathrm{C}$. The photosynthesis measurements started at a $\mathrm{CO}_{2}$ concentration surrounding the leaf $\left(C_{\mathrm{a}}\right)$ of $400 \mu \mathrm{mol} \mathrm{mol}{ }^{-1}$ and a saturating PPFD of $2,000 \mu \mathrm{mol} \mathrm{m} \mathrm{m}^{-2} \mathrm{~s}^{-1}$. Once steady state was reached (usually $20 \mathrm{~min}$ after clamping the leaf), data were recorded. Immediately after that, the air inlet pipe was replaced with medical gas bag with $2 \% \mathrm{O}_{2}$ and $98 \% \mathrm{~N}_{2}$, and a $\mathrm{CO}_{2}$-response curve $\left(P_{\mathrm{N}} / C_{\mathrm{i}}\right.$ curve; $C_{\mathrm{i}}-$ the intercellular $\mathrm{CO}_{2}$ concentration) was performed. After that, $L i-C O R$ inlet was disconnected from $\mathrm{N}_{2}$ medical gas bag (i.e., air with $21 \% \mathrm{O}_{2}$ was supplied again to the plant). After reaching steady state, another $P_{\mathrm{N}} / C_{\mathrm{i}}$ curve was performed. Gas exchange and Chl fluorescence were first measured at $400 \mu \mathrm{mol} \mathrm{mol}{ }^{-1}$, then $C_{\mathrm{a}}$ was decreased

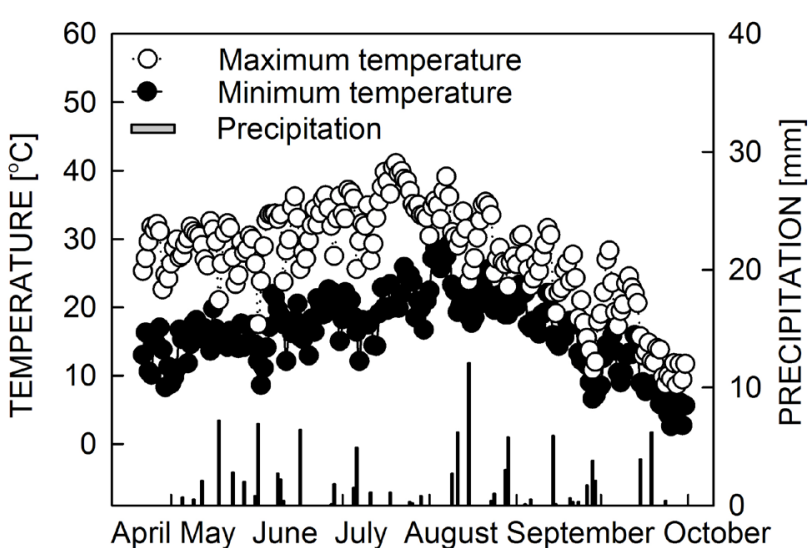

Fig. 1. Daily maximum (open circles) and minimum (solid circles) air temperature and precipitation (bars) during the growing season at the experimental field. 
stepwise until $50 \mu \mathrm{mol} \mathrm{mol} \mathrm{m}^{-1}$, upon completion of measurements at low $C_{\mathrm{a}}$, this was returned to $400 \mu \mathrm{mol} \mathrm{mol}^{-1}$ to restore the original $P_{\mathrm{N}}$. Then, $C_{\mathrm{a}}$ was increased stepwise to complete the curve. The number of different $C_{\mathrm{a}}$ values used for the curves was 12, and the time interval between two consecutive measurements at different $C_{\text {a }}$ was restricted to 2-4 min, so that each curve was completed in 30-50 min. Leakage of $\mathrm{CO}_{2}$ into and out the leaf cuvette was determined with photosynthetically inactive leaves of each species enclosed in the leaf chamber (obtained by heating the leaves until no variable Chl fluorescence was observed), and used to correct measured leaf fluxes (Flexas et al. 2007). The steady-state fluorescence $\left(\mathrm{F}_{\mathrm{s}}\right)$ and maximum fluorescence during the multiphase saturation pulse flash [a light-saturating pulse at the end of phase 1 was $c a$. 8,000 $\mu$ mol(photon) $\left.\mathrm{m}^{-2} \mathrm{~s}^{-1}\right]\left(\mathrm{F}_{\mathrm{m}}{ }^{\prime}\right)$ were estimated, and the actual photochemical efficiency of PSII $\left(\Phi_{\text {PSII }}\right)$ was calculated as $\left(\mathrm{F}_{\mathrm{m}}{ }^{\prime}-\mathrm{F}_{\mathrm{s}}\right) / \mathrm{F}_{\mathrm{m}}{ }^{\prime}$ (Genty et al. 1989). The electron transport rate $\left(J_{\mathrm{flu}}\right)$ was then calculated as $\Phi_{\text {PSII }} \times \alpha \times \beta \times$ PPFD, where $\alpha$ is leaf absorptance and $\beta$ reflects the partitioning of absorbed quanta between PSI and PSII. The term $\alpha$ was assumed to be 0.85 and $\beta$ assumed value was 0.5 . Numerous studies have shown that the estimation of $J_{\text {flu }}$ is affected by PSI and the signalto-noise ratio in the determination of $\mathrm{F}_{\mathrm{m}}{ }^{\prime}$ at high light. To overcome the uncertainties, electron transport from gas exchange $\left(J_{\mathrm{A}}\right)$ under $2 \% \mathrm{O}_{2}$ conditions was used to calibrate $J_{\text {flu }}$ (see Pons et al. 2009 for details).

Estimation of mesophyll conductance, $g_{\mathrm{m}}$, by gas exchange and $C h l$ fluorescence and by the $\boldsymbol{P}_{\mathrm{N}} / \boldsymbol{C}_{\mathrm{i}}$ curve fitting: Mesophyll conductance $\left(g_{\mathrm{m}}\right)$ was estimated according to the method of Harley et al. (1992), as follows:

$g_{\mathrm{m}}=\frac{P_{\mathrm{N}}}{C_{\mathrm{i}}-\frac{\Gamma * \times\left(U_{\text {flu }}+8 \times\left(P_{\mathrm{N}}+R_{\mathrm{d}}\right)\right)}{J_{\text {flu }}-4 \times\left(P_{\mathrm{N}}+R_{\mathrm{d}}\right)}}$

where $P_{\mathrm{N}}$ and $C_{\mathrm{i}}$ were taken from gas-exchange measurements at saturating light. $\Gamma^{*}$ is the $\mathrm{CO}_{2}$-compensation point in the absence of mitochondrial respiration, and $R_{\mathrm{d}}$ is day respiration. $\Gamma^{*}$ was taken according to Bernacchi et al. (2002) $\left[\Gamma^{*}=\operatorname{EXP}\left(13.49-24,460 / 8.314 /\left(273.15+T_{\mathrm{L}}\right)\right)\right.$, where $T_{\mathrm{L}}$ is the leaf temperature in $\left.{ }^{\circ} \mathrm{C}\right]$. $R_{\mathrm{d}}$ was assumed to be 0.5 times of the measured dark respiration $\left(R_{\mathrm{d}}=\right.$ $R_{\mathrm{D}} / 2$ ) (Piel et al. 2002, Niinemets et al. 2005). $R_{\mathrm{D}}$ was determined by gas-exchange measurement ( $\mathrm{Li}$-6400) after plants had been dark-adapted for more than half an hour in the evening. The maximum ribulose-1,5-bisphosphate carboxylation $\left(V_{\mathrm{cmax}}\right)$ and maximum electron transport rate $\left(J_{\max }\right)$ were calculated from the $P_{\mathrm{N}} / C_{\mathrm{c}}$ curves, using the Rubisco kinetic constants and their temperature dependencies described by Bernacchi et al. (2002). The model of Farquhar et al. (1980) was fitted to the data by applying iterative curve-fitting (minimum least-square difference) using the Solver tool of Microsoft Excel (Sharkey 2016). Meanwhile, an alternative estimate of $g_{\mathrm{m}}$ was obtained by the curve-fitting method introduced by Sharkey (2016). This method is based on changes in the curvature of $P_{\mathrm{N}}$ vs. $C_{\mathrm{i}}$ response curves due to a finite $g_{\mathrm{m}}$. By nonlinear curve fitting minimizing the sum of squared model deviations from the data, $g_{\mathrm{m}}$ can be estimated from observed data. The same leaves were used for estimation of $g_{\mathrm{m}}$ by the methods of Sharkey (2016) and Harley et al. (1992).

Relative limitation analyses on $\boldsymbol{P}_{\mathrm{N}}$ : According to Grassi and Magnani (2005), relative stomatal limitation $\left(l_{\mathrm{s}}\right)$, mesophyll limitation $\left(l_{\mathrm{m}}\right)$, and biochemical limitation $\left(l_{\mathrm{b}}\right)$ were investigated, respectively, in the cotton leaves. The quantitative changes in light-saturated assimilation can be expressed in terms of parallel changes in stomatal and mesophyll conductance and in biochemical capacity as follows:

$$
l_{\mathrm{s}}=\frac{\frac{g_{\mathrm{tot}}}{g_{\mathrm{s}}} * \frac{\partial P_{\mathrm{N}}}{\partial C_{\mathrm{c}}}}{g_{\mathrm{tot}}+\frac{\partial P_{\mathrm{N}}}{\partial C_{\mathrm{c}}}}
$$

$l_{\mathrm{m}}=\frac{\frac{g_{\mathrm{tot}}}{g_{\mathrm{m}}} * \frac{\partial P_{\mathrm{N}}}{\partial C_{\mathrm{c}}}}{g_{\mathrm{tot}}+\frac{\partial P_{\mathrm{N}}}{\partial C_{\mathrm{c}}}}$

$l_{\mathrm{b}}=\frac{g_{\mathrm{tot}}}{g_{\mathrm{tot}}+\frac{\partial P_{\mathrm{N}}}{\partial C_{\mathrm{c}}}}$

where $g_{\text {tot }}$ is total conductance to $\mathrm{CO}_{2}$ between the leaf surface and the sites of carboxylation $\left(1 / g_{\text {tot }}=1 / g_{\mathrm{s}}+1 / g_{\mathrm{m}}\right)$; $l_{\mathrm{s}}, l_{\mathrm{m}}$, and $l_{\mathrm{b}}$ are the corresponding relative limitations $\left(0<l_{\mathrm{i}}<1 ; \mathrm{i}=\mathrm{s}, \mathrm{m}, \mathrm{b} ; l_{\mathrm{s}}+l_{\mathrm{m}}+l_{\mathrm{b}}=1\right) . \partial P_{\mathrm{N}} / \partial C_{\mathrm{c}}$ was calculated as the slope of $P_{\mathrm{N}} / C_{\mathrm{c}}$ response curves over a $C_{\mathrm{c}}$ range of 50-100 $\mu \mathrm{mol} \mathrm{mol}{ }^{-1}$ (Tomás et al. 2013).

Light microscopy: After the gas-exchange and Chl fluorescence measurements, sections of $2 \times 2 \mathrm{~mm}$ were cut between the main veins and subjected to microscopic analysis. Leaf samples were fixed by infiltration of 4\% glutaraldehyde and 3\% paraformaldehyde in phosphate buffer $\left(0.1 \mathrm{~mol} \mathrm{~L}^{-1}, \mathrm{pH} 7.2\right)$ under vacuum. Leaf samples were fixed again in $1 \%$ osmium tetroxide overnight and dehydrated in a graded acetone series and embedded in Spurr's resin. Semi-thin $(1 \mu \mathrm{m})$ cross-sections were prepared with an ultramicrotome (Leica Ultracut $R$ ). Semithin cross-sections for light microscopy were stained with $0.5 \%$ toluidine blue and observed under light microscope with a digital camera $(B H-2$, Olympus). Leaf thickness ( $\left.\mathrm{T}_{\text {leaf }}\right)$, the thickness of palisade and spongy tissue layers were obtained and six different positions were measured in each sample.

The mass per area and nitrogen content: Leaf mass per unit area (LMA) is the ratio of dry mass and leaf area. Dry mass was determined from oven-dried certain area of leaf discs after $48 \mathrm{~h}$ at $c a .80^{\circ} \mathrm{C}$. Dividing LMA by leaf thickness is defined as leaf density.

For the measurement of the nitrogen content, leaves were harvested on the same day. Total nitrogen content of the dried tissues was determined according to the microKjeldahl method (Schuman et al. 1972). 
Statistical analysis was performed with SPSS 17.0 for Windows (SPSS Inc., Chicago, IL, USA). All data were tested by analysis of variance (ANOVA). The significance of differences between treatment means were separated by using Student-Newman-Keuls (S-N-K) test at the 0.05 probability level. Data are presented as the means \pm standard errors of three replicates. Interrelations between variables by means of linear regression analysis were investigated.

\section{Results}

The daily minimum and maximum temperature and precipitation during the growing season at the experimental field is shown in Fig. 1; we conducted this experiment in mid-July. The upland cotton had higher area-based net photosynthetic rate $\left(P_{\text {area }}\right)$, mesophyll conductance $\left(g_{\mathrm{m} \text {-area }}\right)$, maximum carboxylation rate $\left(V_{\text {cmax-area }}\right)$, and maximum electron transport rate $\left(J_{\text {max-area }}\right)$ than that of pima cotton (Table 1). Pooling all the data, $P_{\text {area }}$ positively correlated with $g_{\mathrm{s}}, g_{\text {m-area }}$, and $V_{\text {cmax-area. }}$. Moreover, there was close relationship between $g_{\mathrm{m} \text {-area }}$ and $V_{\text {cmax-area }}$ and the drawdown in $\mathrm{CO}_{2}$ between substomatal cavities and the sites of carboxylation within chloroplasts $\left(C_{\mathrm{i}}-C_{\mathrm{c}}\right)$, respectively (Fig. 3). A quantitative limitation analysis following Grassi and Magnani (2005) revealed different weights for each potential limitation (Fig. 4). Only the relative mesophyll limitation $\left(l_{\mathrm{m}}\right)$ dominated in pima cotton, but $l_{\mathrm{m}}$ and biochemical limitation $\left(l_{\mathrm{b}}\right)$ appear to co-limit photosynthesis in upland cotton.

From the analysis of leaf structure (Table 2), upland cotton had higher leaf mass per area (LMA) contributed by higher leaf thickness ( $\mathrm{T}_{\text {leaf }}$ ) than that of pima cotton. Palisade thickness $\left(T_{p}\right)$ and spongy thickness $\left(T_{s}\right)$ in upland cotton were also larger than those in pima cotton. LMA was positively correlated with $P_{\text {area, }}, g_{\text {m-area }}$, and $V_{\text {cmax-area }}$ (Fig. 5). Although upland cotton had higher area-based nitrogen content $\left(\mathrm{N}_{\text {area }}\right)$ than that of pima cotton, there was no significant difference in mass-based nitrogen content $\left(\mathrm{N}_{\text {mass }}\right)$ between upland and pima cotton. Furthermore, interestingly, we converted the area-based photosynthetic parameters into mass-based ones according to available leaf mass per area (LMA) and found there was no significant difference in $P_{\text {mass }}, g_{\text {m-mass}}$, and $V_{\text {cmax-mass }}$ between upland and pima cotton (Table 1). Also, pooling all of the data, a closer relationship between $\mathrm{T}_{\text {leaf }}$ and LMA was observed than that between $\mathrm{D}_{\text {leaf }}$ and LMA (Fig. 6), which was also shown clearly in Fig. 7.

\section{Discussion}

Area-based net photosynthetic rate $\left(P_{\text {area }}\right)$ was significantly higher in upland cotton than that in pima cotton (Table 1), which is consistent with other studies (Zhang et al. 2011). Zhang et al. (2011) have shown that stomatal conductance $\left(g_{\mathrm{s}}\right)$ mainly contributed to the difference in $P_{\text {area }}$ between upland and pima cotton (see also Fig. $2 A$ ). But in this study, we found that the low internal $\mathrm{CO}_{2}$ diffusion, i.e., area-based mesophyll conductance $\left(g_{\mathrm{m} \text {-area }}\right)$ was also an important factor causing a low $P_{\text {area }}$ in pima cotton (Table 1 ,

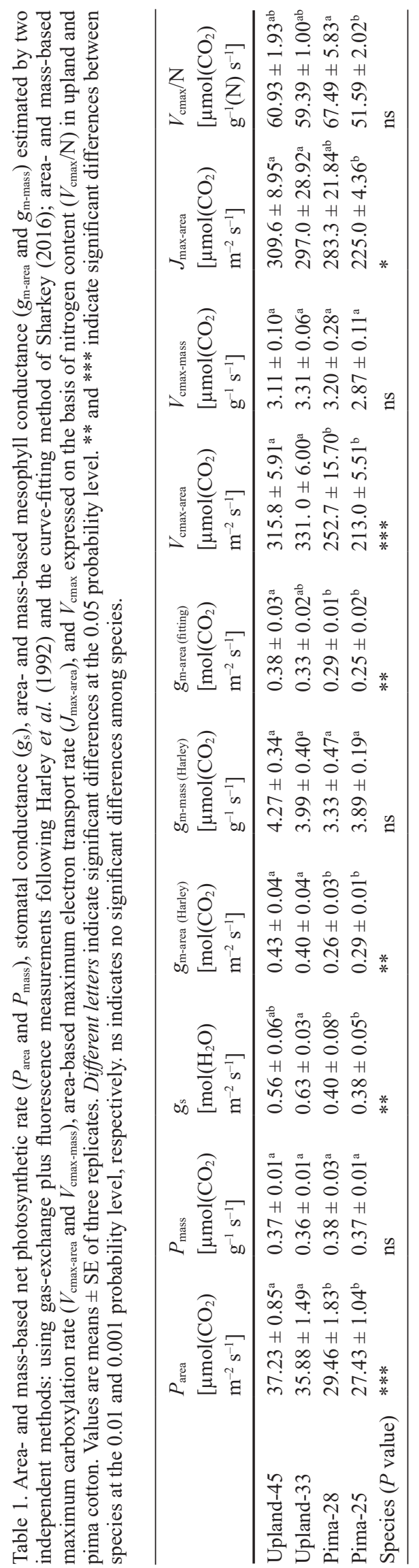




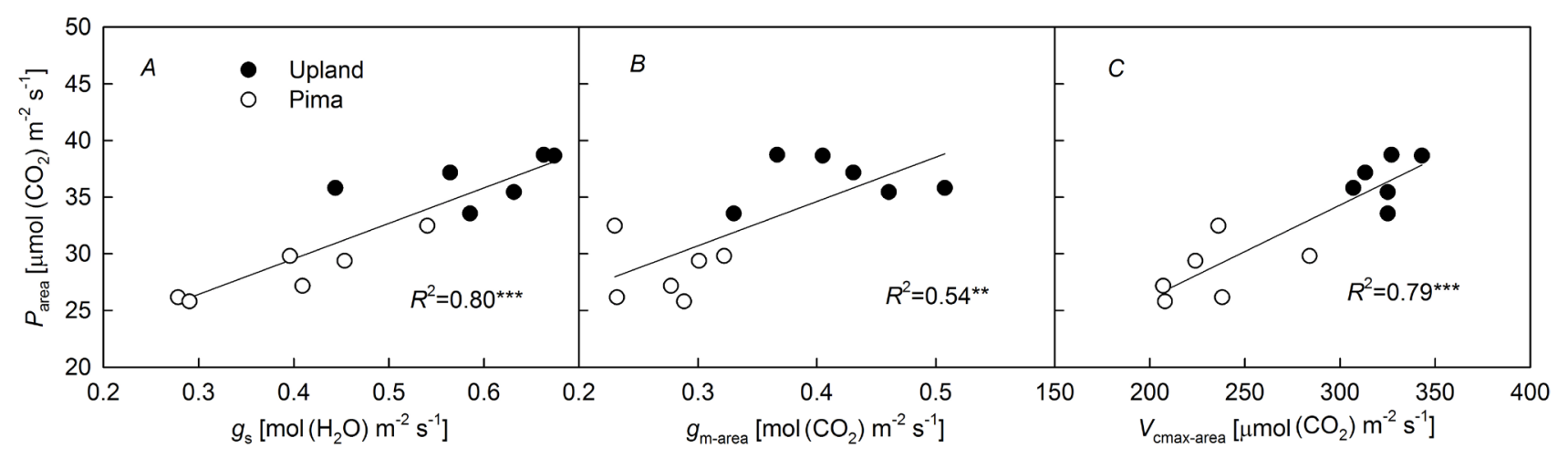

Fig. 2. Area-based net photosynthetic rate $\left(P_{\text {area }}\right)$ as a function of stomatal conductance $\left(g_{\mathrm{s}}\right)(A)$, area-based mesophyll conductance $\left(g_{\text {m-area }}\right)(B)$, and the maximum carboxylation rate $\left(V_{\text {cmax-area }}\right)(C)$, respectively, in upland cotton (solid circles) and pima cotton (open circles). ${ }^{* *}$ and $* * *$ indicate significance at the 0.01 and 0.001 probability level, respectively.

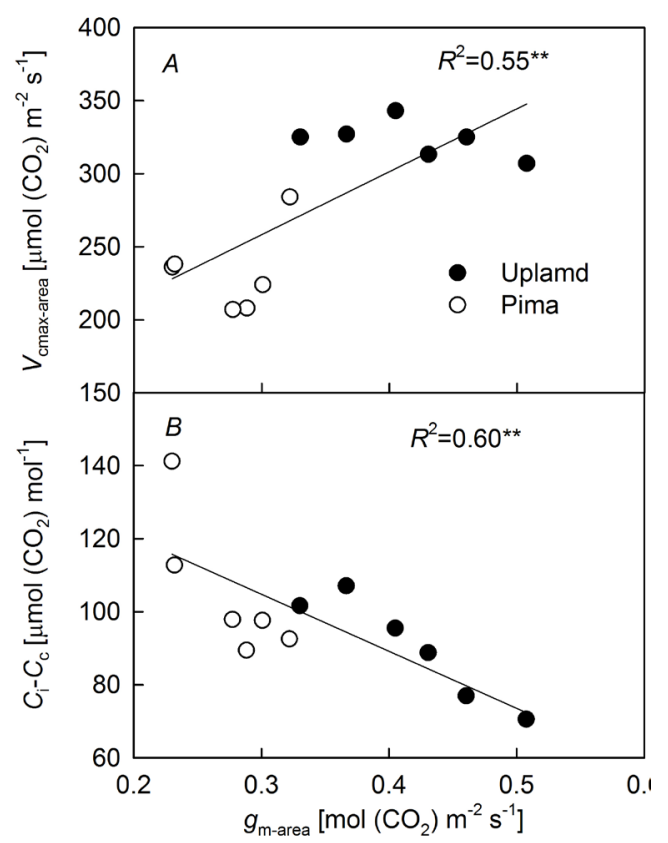

Fig. 3. The relationships between area-based mesophyll conductance $\left(g_{\text {m-area }}\right)$ and the area-based maximum carboxylation rate $\left(V_{\text {cmax-area }}\right)(A)$, and the drawdown in $\mathrm{CO}_{2}$ between substomatal cavities and the sites of carboxylation within chloroplasts $\left(C_{\mathrm{i}}-C_{\mathrm{c}}\right)(B)$ in upland (solid circles) and pima cotton (open circles). The solid lines are the linear regressions; $* * *$ indicate significance at the 0.001 probability level.

Fig. 2B,C). Ellsworth et al. (2018) indicated that the drawdown in $\mathrm{CO}_{2}$ between substomatal cavities and the sites of carboxylation within chloroplasts $\left(C_{\mathrm{i}}-C_{\mathrm{c}}\right)$ should always be estimated to assess the influence of $g_{\text {m-area }}$ on $P_{\text {area }}$. There was a negative correlation between $C_{\mathrm{i}}-C_{\mathrm{c}}$ and $g_{\mathrm{m} \text {-area }}$ (Fig. 3), suggesting that upland cotton leaves with greater $g_{\mathrm{m} \text {-area }}$ do have lower mesophyll diffusion limitations of photosynthesis (Niinemets and Sack 2006, Warren and Adams 2006, Warren 2008) and then higher $\mathrm{CO}_{2}$ concentration at the sites of carboxylation within chloroplasts $\left(C_{\mathrm{c}}\right)$ and $P_{\mathrm{N}}$. Besides the $\mathrm{CO}_{2}$ diffusional limitation, $P_{\text {area }}$ correlated strongly with the area-based maximum carboxylation rate $\left(V_{\text {cmax-area }}\right)$ (Fig. $2 C$ ) that can

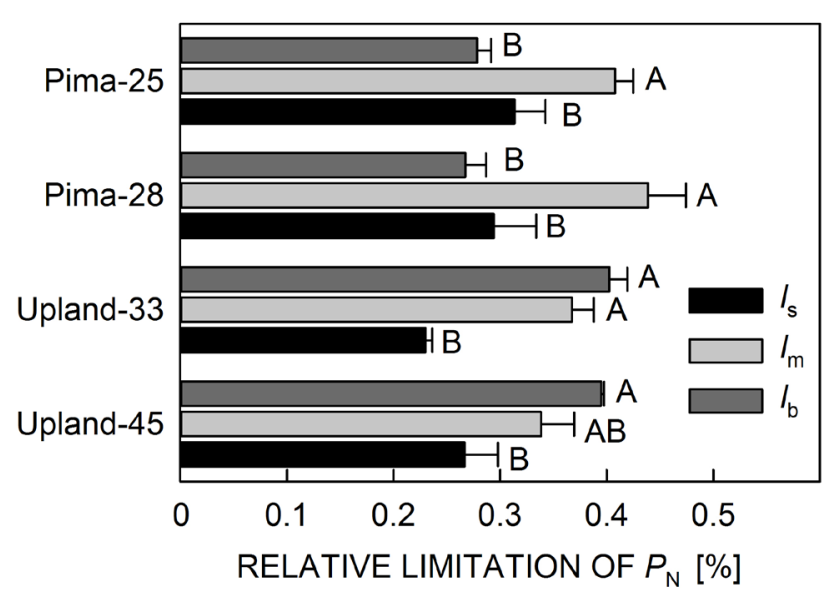

Fig. 4. The relative limitations analysis to net photosynthetic rate $\left(P_{\mathrm{N}}\right)$ imposed by stomatal conductance $\left(l_{\mathrm{s}}\right)$, mesophyll conductance $\left(l_{\mathrm{m}}\right)$, and biochemistry $\left(l_{\mathrm{b}}\right)$ for upland and pima cotton species. Values are means \pm SE of three replicates. Different letters indicate significant differences between three limitations within cultivar at the 0.05 probability level.

reflect biochemical capacity just like Rubisco activity (Flexas et al. 2014). Study has shown that Rubisco activity was regulated by $C_{\mathrm{c}}$ (Galmés et al. 2011), and $V_{\text {cmax-area }}$ was closely related with $g_{\mathrm{m} \text {-area }}$ in this study, suggesting that the $\mathrm{CO}_{2}$ diffusion limitation and biochemical limitation tightly co-regulated photosynthesis. A quantitative limitation analysis following Grassi and Magnani (2005) revealed different weights for each potential limitation (Fig. 4). Only the relative mesophyll limitation $\left(l_{\mathrm{m}}\right)$ dominated in pima cotton, but $l_{\mathrm{m}}$ and biochemical limitation $\left(l_{\mathrm{b}}\right)$ appeared to co-limit photosynthesis in upland cotton. Indeed, from this limitation weight analysis, none of these three limitations can be ignored in setting the differences between upland and pima cotton.

There is always a trade-off between photosynthetic physiological and structural characteristics as reported by most studies. Leaves with higher leaf mass per area (LMA) tend to have higher investment in nonphotosynthetic tissue and this leads to lower photosynthetic efficiency (Niinemets et al. 2009a, Hassiotou et al. 2010). Meanwhile, 
Table 2. Leaf mass per unit area (LMA), leaf thickness $\left(T_{\text {leaf }}\right)$, leaf density $\left(D_{\text {leaf }}\right)$, palisade thickness $\left(T_{p}\right)$, spongy thickness $\left(T_{s}\right)$, and mass- and area-based nitrogen $\left(\mathrm{N}_{\text {mass }}\right.$ and $\left.\mathrm{N}_{\text {area }}\right)$ in upland and pima cotton leaves. Values are means $\pm \mathrm{SE}$ of three replicates. Different letters indicate significant differences at the 0.05 probability level. ** and $* * *$ indicate significant differences between species at the 0.01 and 0.001 probability level, respectively. ns indicates no significant differences among species.

\begin{tabular}{lcllllll}
\hline & LMA $\left[\mathrm{g} \mathrm{m}^{-2}\right]$ & $\mathrm{T}_{\text {leaf }}[\mu \mathrm{m}]$ & $\mathrm{D}_{\text {leaf }}\left[\mathrm{g} \mathrm{cm}^{-3}\right]$ & $\mathrm{T}_{\mathrm{p}}[\mu \mathrm{m}]$ & $\mathrm{T}_{\mathrm{s}}[\mu \mathrm{m}]$ & $\mathrm{N}_{\text {mass }}[\%]$ & $\mathrm{N}_{\text {area }}\left[\mathrm{g} \mathrm{m}^{-2}\right]$ \\
\hline Upland-45 & $101.58 \pm 1.37^{\mathrm{a}}$ & $432.63 \pm 10.98^{\mathrm{a}}$ & $0.236 \pm 0.01^{\mathrm{c}}$ & $199.44 \pm 6.39^{\mathrm{a}}$ & $191.19 \pm 13.85^{\mathrm{a}}$ & $5.11 \pm 0.17^{\mathrm{a}}$ & $5.20 \pm 0.06^{\mathrm{b}}$ \\
Upland-33 & $100.02 \pm 0.59^{\mathrm{a}}$ & $404.95 \pm 7.70^{\mathrm{b}}$ & $0.245 \pm 0.00^{\mathrm{c}}$ & $175.95 \pm 4.02^{\mathrm{b}}$ & $184.61 \pm 7.97^{\mathrm{a}}$ & $5.57 \pm 0.36^{\mathrm{a}}$ & $5.53 \pm 0.05^{\mathrm{a}}$ \\
Pima-28 & $79.02 \pm 2.70^{\mathrm{b}}$ & $266.92 \pm 1.58^{\mathrm{c}}$ & $0.293 \pm 0.00^{\mathrm{a}}$ & $115.54 \pm 2.24^{\mathrm{c}}$ & $103.83 \pm 7.59^{\mathrm{b}}$ & $4.76 \pm 1.66^{\mathrm{a}}$ & $3.72 \pm 0.09^{\mathrm{d}}$ \\
Pima-25 & $74.43 \pm 3.08^{\mathrm{b}}$ & $269.60 \pm 1.66^{\mathrm{c}}$ & $0.275 \pm 0.00^{\mathrm{b}}$ & $107.27 \pm 5.81^{\mathrm{c}}$ & $122.98 \pm 9.07^{\mathrm{b}}$ & $5.56 \pm 0.11^{\mathrm{a}}$ & $4.12 \pm 0.10^{\mathrm{c}}$ \\
Species $(P$ value $)$ & $* * *$ & \multirow{*}{**}{} & $* * *$ & $* * *$ & $* * *$ & $\mathrm{~ns}$ & $* * *$ \\
\hline
\end{tabular}

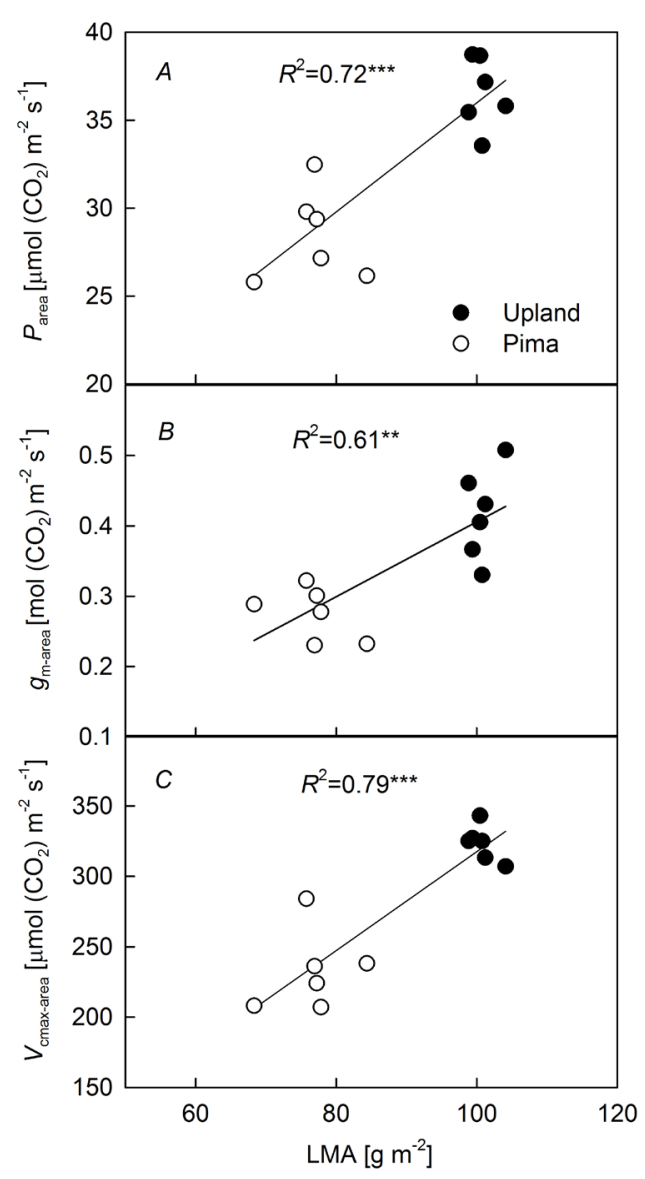

Fig. 5. The relationships between leaf mass per area (LMA) and area-based net photosynthetic rate $\left(P_{\text {area }}\right)(A)$, mesophyll conductance $\left(g_{\text {m-area }}\right)(B)$, and the maximum carboxylation rate $\left(V_{\text {cmax-area }}\right)(C)$, respectively, in upland (solid circles) and pima cotton (open circles). The solid lines are the linear regressions; ** and *** indicate significance at the 0.01 and 0.001 probability level, respectively.

LMA has been suggested to negatively affect the $g_{\mathrm{m} \text {-area }}$ and limit area-based photosynthesis (Flexas et al. 2008). However, in this study, LMA was positively correlated with physiological traits (i.e., $P_{\text {area, }}, g_{\text {m-area }}, V_{\text {cmax-area }}$ (Fig. 5). It is well established that LMA is an integrative trait of leaf structural characteristics and the product of leaf density ( $\left.\mathrm{D}_{\text {leaf }}\right)$ and thickness $\left(\mathrm{T}_{\text {leaf }}\right)$ (Poorter et al. 2009, Niinemets

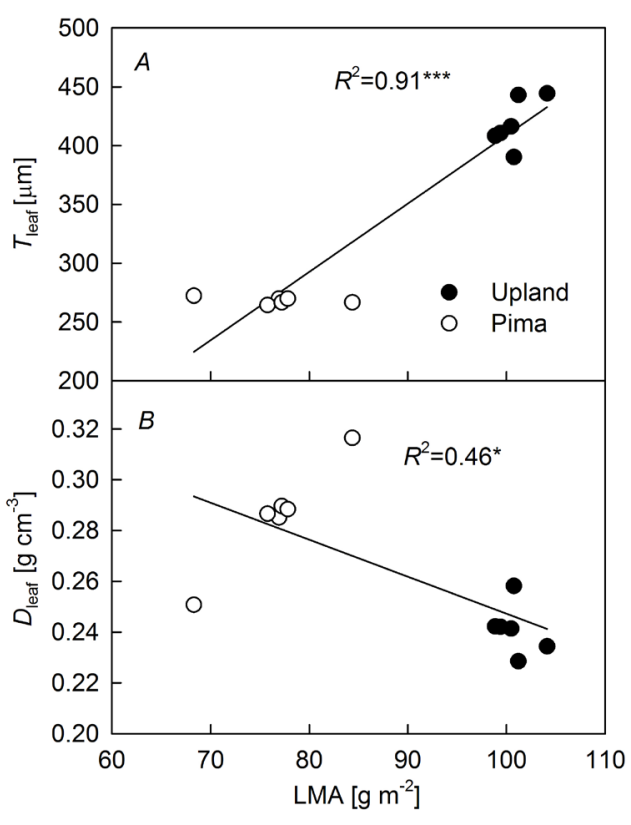

Fig. 6. The relationships between leaf mass per area (LMA) and leaf thickness $\left(\mathrm{T}_{\text {leaf }}\right)(A)$ and leaf density $\left(\mathrm{D}_{\text {leaf }}\right)(B)$, respectively, in upland (solid circles) and pima cotton (open circles). The solid lines are the linear regressions; $* * *$ and $*$ indicate significance at the 0.001 and 0.05 probability level, respectively.

2015). Our results showed that the variation in LMA is primarily driven by variations in $\mathrm{T}_{\text {leaf }}$ and to a lesser degree in $\mathrm{D}_{\text {leaf }}$ (Fig. 6). It is likely that upland cotton with higher $\mathrm{T}_{\text {leaf }}$ had more Rubisco carboxylation sites (Flexas et al. 2014) and/or higher surface of chloroplasts exposed to intercellular airspace $\left(S_{\mathrm{c}} / S\right)$ (Hanba et al. 1999, 2002; Terashima et al. 2006, Peguero-Pina et al. 2016), thereby increasing photosynthetic physiological traits.

Generally, photosynthetic characteristics and $\mathrm{CO}_{2}$ diffusion properties were measured on the basis of leaf area, but it is reported that photosynthetic process inside the leaves is based on a three-dimensional structure (Parkhurst 1994, Niinemets et al. 2009b). The massbased photosynthetic traits can be better used to measure the trade-off between the physiological and structural characteristics of leaves (Niinemets et al. 2015). The trait values on the mass basis can be calculated according to available LMA. Interestingly, it was documented that 


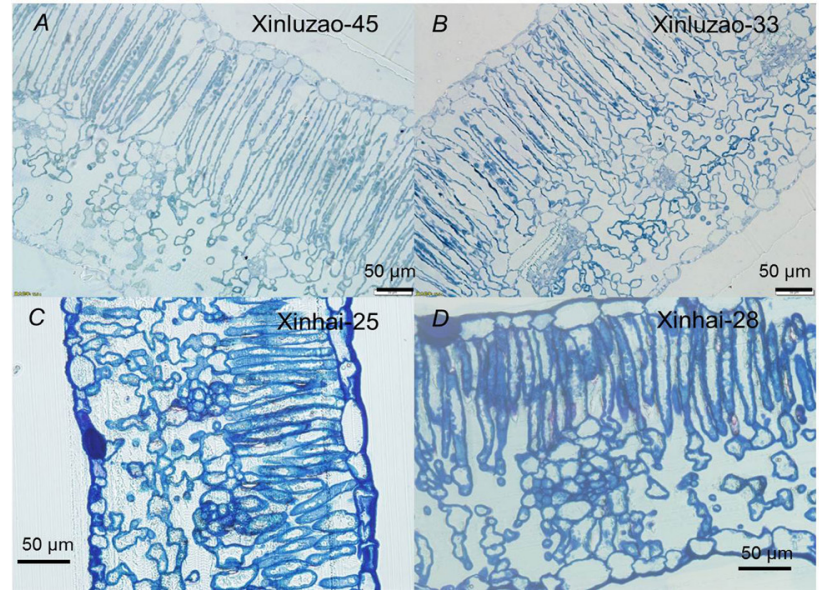

Fig. 7. Light microscopy images of upland Xinluzao $45(A)$ and Xinluzao $33(B)$, and pima Xinhai $25(C)$ and Xinhai $28(D)$ cotton leaves. The black lines represent measuring scales of $50 \mu \mathrm{m}$.

mass-based $V_{\text {cmax }}\left(V_{\text {cmax-mass }}\right)$ is more effective in separating biochemical from anatomical effects on $P_{\mathrm{N}}$ than $V_{\text {cmax-area }}$ (Ellsworth et al. 2018); $g_{\mathrm{m} \text {-mass }}$ is more strongly related to photosynthetic tissue volume than to the area; the $P_{\text {mass }}$ is the key player in the trade-off between the physiological and structural characteristics of leaves (Westoby et al. 2013, Niinemets et al. 2015). In our study, no difference in $P_{\text {mass }}, g_{\mathrm{m} \text {-mass, }}$, and $V_{\text {cmax-mass }}$ between upland and pima cotton was observed, indicating that both of upland and pima cotton had the similar photosynthetic capacity of single cells. Moreover, there was no significant difference in nitrogen investment. A similar carboxylation capacity per unit of nitrogen (i.e., $V_{\text {cmax }} / \mathrm{N}$ ) suggests that upland and pima cotton divert a similar proportion of their $\mathrm{N}$ to nonphotosynthetic compounds. Therefore, the higher trait values on the basis of area in upland cotton were only due to higher $\mathrm{T}_{\text {leaf }}$ or LMA. This was inconsistent with the change rule of data in the global databases, but keeping in mind that only four species were studied and these belonged to the trade-off within species that has not been proved to be consistent with the laws along species.

Conclusion: Upland cotton had higher area-based net photosynthetic rate $\left(P_{\text {area }}\right)$ than that of pima cotton, which was attributed to the coordination of area-based stomatal conductance $\left(g_{\mathrm{s}}\right)$, mesophyll conductance $\left(g_{\mathrm{m} \text {-area }}\right)$, and biochemical capacity (i.e., $V_{\text {cmax-area }}$ and $\left.J_{\text {max-area }}\right) . P_{\text {area, }} g_{\text {m-area, }}$ and $V_{\text {cmax-area }}$ correlated positively with leaf mass per area (LMA). But there was no difference in mass-based $P_{\mathrm{N}}\left(P_{\text {mass }}\right), g_{\mathrm{m}}\left(g_{\text {m-mass }}\right)$, and $V_{\text {cmax }}\left(V_{\text {cmax-mass }}\right)$ between upland and pima cotton, suggesting that upland and pima cotton had a similar photosynthetic capacity of single cells. Therefore, we can conclude that the higher trait values on the basis of area in upland cotton were only due to higher $\mathrm{T}_{\text {leaf }}$ or LMA.

\section{References}

Bernacchi C.J., Portis A.R., Nakano H. et al.: Temperature response of mesophyll conductance. Implications for the determination of Rubisco enzyme kinetics and for limitations to photosynthesis in vivo. - Plant Physiol. 130: 1992-1998, 2002.

Ellsworth P.V., Ellsworth P.Z., Koteyeva N.K., Cousins A.B.: Cell wall properties in Oryza sativa influence mesophyll $\mathrm{CO}_{2}$ conductance. - New Phytol. 219: 66-76, 2018.

Ethier G.J., Livingston N.J.: On the need to incorporate sensitivity to $\mathrm{CO}_{2}$ transfer conductance into the Farquharvon Caemmerer-Berry leaf photosynthesis model. - Plant Cell Environ. 27: 137-153, 2004.

Evans J.R., Kaldenhoff R., Genty B., Terashima I.: Resistances along the $\mathrm{CO}_{2}$ diffusion pathway inside leaves. - J. Exp. Bot. 60: 2235-2248, 2009.

Evans J.R., Sharkey T.D., Berry J.A., Farquhar G.D.: Carbon isotope discrimination measured concurrently with gas exchange to investigate $\mathrm{CO}_{2}$ diffusion in leaves of higher plants. - Aust. J. Plant Physiol. 13: 281-292, 1986.

Farquhar G.D., von Caemmerer S., Berry J.A.: A biochemical model of photosynthetic $\mathrm{CO}_{2}$ assimilation in leaves of $\mathrm{C}_{3}$ species. - Planta 149: 78-90, 1980.

Flexas J.: Genetic improvement of leaf photosynthesis and intrinsic water use efficiency in $\mathrm{C}_{3}$ plants: Why so much little success? - Plant Sci. 251: 155-161, 2016.

Flexas J., Barbour M.M., Brendel O. et al.: Mesophyll diffusion conductance to $\mathrm{CO}_{2}$ : An unappreciated central player in photosynthesis. - Plant Sci. 193-194: 70-84, 2012.

Flexas J., Díaz-Espejo A., Conesa M.A. et al.: Mesophyll conductance to $\mathrm{CO}_{2}$ and Rubisco as targets for improving intrinsic water use efficiency in $\mathrm{C}_{3}$ plants. - Plant Cell Environ. 39: 965-982, 2016.

Flexas J., Diaz-Espejo A., Gago J. et al:: Photosynthetic limitations in Mediterranean plants: A review. - Environ. Exp. Bot. 103: 12-23, 2014.

Flexas J., Diaz-Espejo A., Galmés J. et al.: Rapid variations of mesophyll conductance in response to changes in $\mathrm{CO}_{2}$ concentration around leaves. - Plant Cell Environ. 30: 1284-1298, 2007.

Flexas J., Ribas-Carbó M., Bota J. et al.: Decreased Rubisco activity during water stress is not induced by decreased relative water content but related to conditions of low stomatal conductance and chloroplast $\mathrm{CO}_{2}$ concentration. New Phytol. 172: 73-82, 2006.

Flexas J., Ribas-Carbó M., Diaz-Espejo A. et al.: Mesophyll conductance to $\mathrm{CO}_{2}$ : current knowledge and future prospects. Plant Cell Environ. 31: 602-621, 2008.

Gago J., Daloso D.M., Figueroa C.M. et al.: Relationships of leaf net photosynthesis, stomatal conductance, and mesophyll conductance to primary metabolism: A multispecies metaanalysis approach. - Plant Physiol. 171: 265-279, 2016.

Galmés J., Ribas-Carbó M., Medrano H., Flexas J.: Rubisco activity in Mediterranean species is regulated by the chloroplastic $\mathrm{CO}_{2}$ concentration under water stress. - J. Exp. Bot. 62: 653-665, 2011.

Genty B., Briantais J.M., Baker N.R.: The relationship between the quantum yield of photosynthetic electron transport and quenching of chlorophyll fluorescence. - Biochim. Biophys. Acta 990: 87-92, 1989.

Grassi G., Magnani F.: Stomatal, mesophyll conductance and biochemical limitations to photosynthesis as affected by drought and leaf ontogeny in ash and oak trees. - Plant Cell Environ. 28: 834-849, 2005.

Gu L., Sun Y.: Artefactual responses of mesophyll conductance to $\mathrm{CO}_{2}$ and irradiance estimated with the variable $J$ and online isotope discrimination methods. - Plant Cell Environ 37: 1231-1249, 2014.

Hanba Y.T., Kogami H., Terashima I.: The effect of growth 
irradiance on leaf anatomy and photosynthesis in Acer species differing in light demand. - Plant Cell Environ. 25: 1021-1030, 2002.

Hanba Y.T., Miyazawa S.I., Terashima I.: The influence of leaf thickness on the $\mathrm{CO}_{2}$ transfer. - Funct. Ecol. 13: 632-639, 1999.

Harley P.C., Loreto F., Di Marco G., Sharkey T.D: Theoretical considerations when estimating the mesophyll conductance to $\mathrm{CO}_{2}$ flux by the analysis of the response of photosynthesis to $\mathrm{CO}_{2}$. - Plant Physiol. 98: 1429-1436, 1992.

Hassiotou F., Renton M., Ludwig M. et al.: Photosynthesis at an extreme end of the leaf trait spectrum: how does it relate to high leaf dry mass per area and associated structural parameters? - J. Exp. Bot. 61: 3015-3028, 2010.

Kattge J., Díaz S., Lavorel S. et al.: TRY - a global database of plant traits. - Glob. Change Biol. 17: 2905-2935, 2011.

Nadal M., Flexas J.: Mesophyll conductance to $\mathrm{CO}_{2}$ diffusion of drought and opportunities for improvement. - In: García Tejero I.F., Durán Zuazo V.H. (ed.): Water Scarcity and Sustainable Agriculture in Semiarid Environment. Pp. 403-438. Academic Press 2018.

Niinemets Ü.: Components of leaf dry mass per area - thickness and density - alter leaf photosynthetic capacity in reverse directions in woody plants. - New Phytol. 144: 35-47, 1999.

Niinemets Ü.: Global-scale climatic controls of leaf dry mass per area, density, and thickness in trees and shrubs. - Ecology 82: 453-469, 2001.

Niinemets Ü.: Is there a species spectrum within the world-wide leaf economics spectrum? Major variations in leaf functional traits in the Mediterranean sclerophyll Quercus ilex. - New Phytol. 205: 79-96, 2015.

Niinemets Ü., Cescatti A., Rodeghiero M., Tosens T.: Leaf internal diffusion conductance limits photosynthesis more strongly in older leaves of Mediterranean evergreen broadleaved species. - Plant Cell Environ. 28: 1552-1566, 2005.

Niinemets Ü., Díaz-Espejo A., Flexas J. et al.: Role of mesophyll diffusion conductance in constraining potential photosynthetic productivity in the field. - J. Exp. Bot. 60: 2249-2270, 2009b.

Niinemets Ü., Keenan T.F., Hallik L.: A worldwide analysis of within-canopy variations in leaf structural, chemical and physiological traits across plant functional types. - New Phytol. 205: 973-993, 2015.

Niinemets Ü., Reichstein M.: Controls on the emission of plant volatiles through stomata: A sensitivity analysis. - J. Geophys. Res.-Atmos. 108: 4208, 2003.

Niinemets Ü., Sack L.: Structural determinants of leaf lightharvesting capacity and photosynthetic potentials. - In: Esser K., Luttge U.E., Beyschlag W., Murata J. (ed.): Progress in Botany. Vol. 67. Pp. 385-419. Springer Verlag, Berlin 2006.

Niinemets Ü., Wright I.J., Evans J.R.: Leaf internal diffusion conductance in 35 Australian species covering extreme low end of foliage nutrients and high end of leaf structural robustness. - J. Exp. Bot. 60: 2433-2449, 2009a.

Parkhurst D.F.: Diffusion of $\mathrm{CO}_{2}$ and other gases inside leaves. New Phytol. 126: 449-479, 1994.

Peguero-Pina J.J., Sisó S., Sancho-Knapik D. et al.: Leaf morphological and physiological adaptations of a deciduous oak (Quercus faginea Lam.) to the Mediterranean climate: a comparison with a closely related temperate species (Quercus robur L.). - Tree Physiol. 36: 287-299, 2016.

Piel C., Frak E., Le Roux X., Genty B.: Effect of local irradiance on $\mathrm{CO}_{2}$ transfer conductance of mesophyll in walnut. - J. Exp. Bot. 53: 2423-2430, 2002.

Pons T.L., Flexas J., von Caemmerer S. et al.: Estimating mesophyll conductance to $\mathrm{CO}_{2}$ : methodology, potential errors, and recommendations. - J. Exp. Bot. 60: 2217-2234, 2009.

Poorter H., Niinemets Ü., Poorter L. et al.: Causes and consequences of variation in leaf mass per area (LMA): a metaanalysis. - New Phytol. 182: 565-588, 2009.

Reich P.B., Walters M.B., Ellsworth D.S.: From tropics to tundra: Global convergence in plant functioning. - P. Natl. Acad. Sci. USA 94: 13730-13734, 1997.

Schuman G.E., Stanley M.A., Knudsen D.: Automated total nitrogen analysis of soil and plant samples. - Soil Sci. Soc. Am. J. 37: 480-481, 1972.

Sharkey T.D., Bernacchi C.J., Farquhar G.D., Singsaas E.L.: Fitting photosynthetic carbon dioxide response curves for $\mathrm{C}_{3}$ leaves. - Plant Cell Environ. 30: 1035-1040, 2007.

Sharkey T.D.: What gas exchange data can tell us about photosynthesis. - Plant Cell Environ. 39: 1161-1163, 2016.

Terashima I., Hanba Y.T., Tazoe Y. et al.: Irradiance and phenotype: comparative eco-development of sun and shade leaves in relation to photosynthetic $\mathrm{CO}_{2}$ diffusion. - J. Exp. Bot. 57: 343-354, 2006.

Terashima I., Hanba Y.T., Tholen D., Niinemets Ü.: Leaf functional anatomy in relation to photosynthesis. - Plant Physiol. 155: 108-116, 2011.

Tomás M., Flexas J., Copolovici L. et al.: Importance of leaf anatomy in determining mesophyll diffusion conductance to $\mathrm{CO}_{2}$ across species: quantitative limitations and scaling up by models. - J. Exp. Bot. 64: 2269-2281, 2013.

Tosens T., Nishida K., Gago J. et al.: The photosynthetic capacity in 35 ferns and fern allies: mesophyll $\mathrm{CO}_{2}$ diffusion as a key trait. - New Phytol. 209: 1576-1590, 2016.

Warren C.R.: Stand aside stomata, another actor deserves centre stage: the forgotten role of the internal conductance to $\mathrm{CO}_{2}$ transfer. - J. Exp. Bot. 59: 1475-1487, 2008.

Warren C.R., Adams M.A.: Internal conductance does not scale with photosynthetic capacity: implications for carbon isotope discrimination and the economics of water and nitrogen use in photosynthesis. - Plant Cell Environ. 29: 192-201, 2006.

Westoby M., Reich P.B., Wright I.J.: Understanding ecological variation across species: area-based vs mass-based expression of leaf traits. - New Phytol. 199: 322-323, 2013.

Wright I.J., Groom P.K., Lamont B.B. et al.: Leaf trait relationships in Australian plant species - Funct. Plant Biol. 31: 551-558, 2004a.

Wright I.J., Reich P.B., Westoby M. et al.: The world-wide leaf economics spectrum. - Nature 428: 821-827, 2004b.

Zhang Y.L., Yao H.S., Luo Y. et al.: Difference in leaf photosynthetic capacity between pima cotton (Gossypium barbadense) and upland cotton (G. hirsutum) and analysis of potential constraints. - Acta Ecol. Sin. 31: 1803-1810, 2011. [In Chinese]

(C) The authors. This is an open access article distributed under the terms of the Creative Commons BY-NC-ND Licence. 